\title{
有機超伝導体の電解合成と最近の発展
}

\author{
山田 順一・梅宮 将充 \\ 兵庫県立大学大学院物質理学研究科 丵 678-1297 兵庫県赤穂郡上郡町光都 3-2-1
}

（2006 年 6 月 1 日受理）

\section{Synthesis of Organic Superconductors by Electrocrystallization and Recent Advances in Development of Organic Superconductors}

\author{
Jun-ichi YAMADA and Masamichi UMEMIYA \\ Department of Material Science, Graduate School of Material Science, University of Hyogo \\ 3-2-1 Kouto, Kamigori-cho, Ako-gun, Hyogo 678-1297
}

(Received June 1, 2006)

\begin{abstract}
Since an organic superconductor (TMTSF) ${ }_{2} \mathrm{PF}_{6}$ was discovered, many researches have been directed toward the achievement of organic superconductivity. A great number of organic superconductors are now known, most of which are chargetransfer (CT) salts. Electrocrystallization is a powerful tool for the preparation of CT salts, including those with superconductivity. Recently, new types of organic superconductors, such as non-TTF-based superconductors and magnetic superconductors with the field-induced superconductivity and with superconductor-insulator transitions, have been developed.
\end{abstract}

\section{1. は じめに}

三十数年程前は，有機物質が金属，ましては超伝導体 になるとは想像すらされていなかった。ところが, 1973 年に，有機ドナー分子（電子供与体）である TTF（Fig. 1）と有機アクセプター分子（電子受容体）である $\mathrm{TCNQ}$ との電荷移動錯体が金属的伝導性を示すことが見出され た1)。この発見を契機に，様々な TTF 誘導体の合成が開 始され2), 有機分子に基づく分子性導体 (Organic (Molecular) Conductor）の研究が盛んに行われるようになっ た ${ }^{3,4)}$ 。この研究をさらに加速したのは, 1980 年に報告 された最初の有機超伝導体 (TMTSF) ${ }_{2} \mathrm{PF}_{6}$ の発見であ る5)。この物質は，2つの有機ドナー分子 (TMTSF) と 1 つの無機アニオン $\left(\mathrm{PF}_{6}^{-}\right)$から成る電荷移動塩である。 その後, 超伝導性を示す一連の BEDT-TTF 塩が見つか り，今日ではおよそ 120 種類の有機超伝導体*が報告さ れている6。

本稿では, 有機超伝導体を含めた電荷移動塩の電解合 成と有機超伝導体に関する最近のトピックスを概要す る。

E-mail: yamada@sci.u-hyogo.ac.jp

*ここでは，フラーレン系超伝導体を除く。

\section{2. 電解による電荷移動塩の作製}

有機ドナー分子 $(\mathrm{D})$ と無機アニオン $\left(\mathrm{X}^{-}\right)$との電荷移動 塩 $\left[(\mathrm{D})_{\mathrm{n}}(\mathrm{X})_{\mathrm{m}}\right]$ は, 電気化学反応を利用して作製する ことができる。たとえば，超伝導体（BEDT-TTF） $2_{2}$ の 結晶は, 有機溶媒中, 支持電解質としてテトラブチルア ンモニウム塩（Bu4NI3） を用いて，BEDT-TTF を電解酸 化することによって得られる。中性の BEDT-TTF 分子 は陽極の表面で，(1)式に従ってラジカルカチオンへ酸 化される。このラジカルカチオンと中性の BEDT-TTF および $\mathrm{I}_{3}$-アニオンから，(2)式に示すように (BEDTTTF) ${ }_{2} \mathrm{I}_{3}$ が形成されて 7 ），結晶が成長するのであろう。

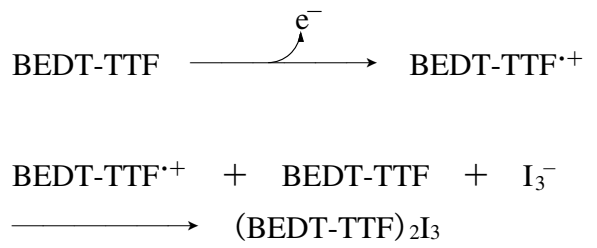

一般に，結晶育成には Fig. 2 (a) に示すような H 型 セルが用いられているが，我々は Fig. 2（b）に示すビ 一カー型のセル ${ }^{8)}$ を使用している。このセルでは, 中心 に置いた陰極を円筒状の陽極で取り巻いて, 陽極表面全 体で酸化反応が起こるように設計されている。また，テ 

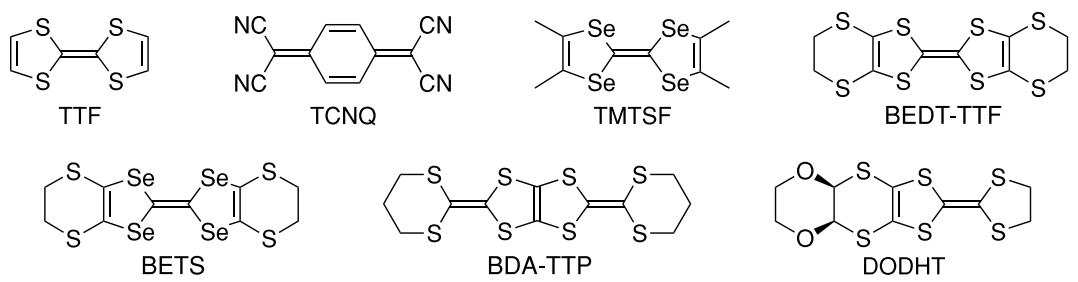

Fig. 1. Organic donor and acceptor molecules for molecular metals and superconductors.

(a)

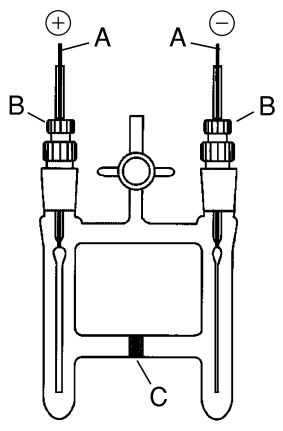

(b)

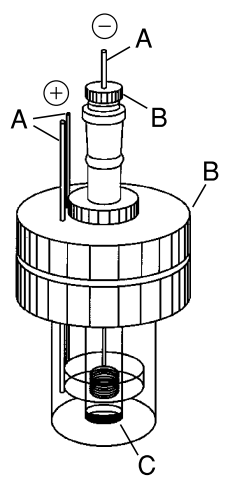

Fig. 2. Glass cells for electrocrystallization. (a) H-type cell.(b) Beaker-type cell. A: Pt electrode, B: Teflon cap, C: glass filter.

(a)

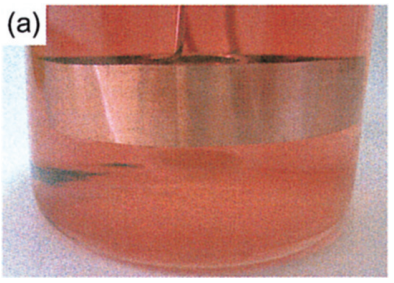

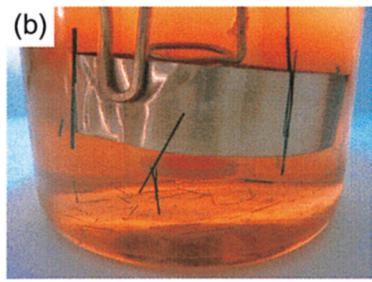

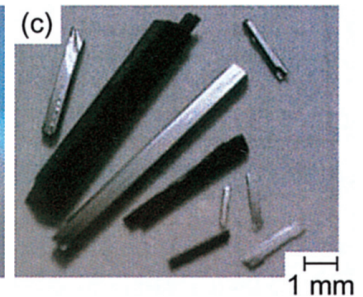

Fig. 3. Crystal growth of (TMTSF) $)_{2} \mathrm{ClO}_{4}$ in a beaker-type cell. (a) Prior to application of a controlled-current.(b) Crystals in growth during applying a controlledcurrent. (c) Single crystals of (TMTSF) ${ }_{2} \mathrm{ClO}_{4}$ obtained by the controlled-current electrocrystallization method.

フロン製のキャップをはずせば，大きな結晶でも容易に 取り出すことができる。

固体物性の研究を促進・発展させるためには, 研究に 適した試料の開発だけではなく，その試料の物性評価を 容易にする「形」にしなければならない。その「形」と は, 試料を良質な単結晶に育成することである。我々は, 電解合成によって良質な単結晶を得るために, 従来の定 電流法とは異なった制御電流法を開発した7)。この方法 では, 成長中の結晶表面にかかる電流を単位時間当たり 一定 $(I / S=\mathrm{c}, I$ : 電流, $S$ : 結晶の表面積, $\mathrm{c}$ : 定数 $)$ として, 電流を時間の二乗に比例するように制御する
$\left(I=\mathrm{c} t^{2}, I:\right.$ 電流, $\mathrm{c}:$ 定数, $t:$ 時間)。

Fig. 3 に，制御電流法による（TMTSF） ${ }_{2} \mathrm{ClO}_{4}$ の結晶育 成過程を示す。Fig. 3 (a) は, 電流を流す前の状態であ る。ビーカー型セルの底に見える結晶は TMTSF である。 電流を流すと, 円筒状の陽極上に (TMTSF) ${ }_{2} \mathrm{ClO}_{4}$ の黒 い針状結晶が成長し始める（Fig. 3 (b)）。大きな単結晶 を得るためのコツは, 陽極上に微少な結晶が観察された ら，一旦，電流を止めることである9)。この時，陽極の 周辺部では, ドナー分子のラジカルカチオンが過飽和 （Supersaturation）状態にあると予想される。もし，電流 を流し続けたら, 陽極上に数多くの微少結晶ができてし 
<smiles>C=C1SC2=C(S1)SC(=C)S2</smiles><smiles>C=C1SC=CS1</smiles>

DT unit

Fig. 4. (a) BDY (bis-fused 1,3-dithiol-2-ylidene) unit and (b) DT (1,3-dithiol-2-ylidene) unit as $\pi$-electron systems of donor molecules leading to organic superconductors.

まい, 大きな結晶に成長することができなくなる。電流 を止めても, 微少結晶はわずかに成長するので, その成 長が終了したことを見極めた後, 再び電流を流し始める。 このようにして作製した（TMTSF） ${ }_{2} \mathrm{ClO}_{4}$ の結晶を Fig. 3 (c) に示す。

(TMTSF) ${ }_{2} \mathrm{ClO}_{4}$ のような電荷移動塩では, 伝導性を担 う電子の軌道は有機ドナー分子の $\pi$ 軌道であり, $\pi$ 電 子はドナー分子間のわずかな軌道の重なりを通って結晶 内を移動することができる。しかし, 有機超伝導性の発 現に関しては，1 つの機構で説明しようとすると，うま く説明できない点が生じてくる, というのが現状であろ う。

\section{3. 非 TTF 系有機超伝導体の開発}

2000 年までに報告された超伝導体を与えるドナー分 子には, すべて TTF あるいはそのセレン誘導体が含ま れていた。したがって, 超伝導性を担うドナー分子の $\pi$ 電子系として, TTF ユニットは必須であると思われて いた。これを打破したのが, 我々が合成に成功した BDATTP（2001 年）とDODHT（2002 年）の出現である ${ }^{10) 。 ~}$ これら 2 つのドナー分子の $\pi$ 電子系は, それぞれ BDY ユニットと DT ユニットであり (Fig. 4), TTF ユニット は含まれていない。それでも, 両者のドナーは超伝導体 を与えることができる。BDA-TTP 系超伝導体の特徵と して, まず, (BDA-TTP) ${ }_{2} \mathrm{SbF}_{6}$ のサイクロトロン有効質 量の值が BEDT-TTF 系超伝導体の約 2 倍であることが あげられる。この結果は, (BDA-TTP) ${ }_{2} \mathrm{SbF}_{6}$ における電 子相関が BEDT-TTF 系超伝導体よりも強いことを示唆 している ${ }^{11)}$ 。また, 有機超伝導体の中で, 超伝導状態へ の転移温度（ $T_{\mathrm{c}}$ ）が $10 \mathrm{~K}$ を超えるものは, それほど多 くはなく, BEDT-TTF と BETS からのみ見つかっている が, 最近, (BDA-TTP) ${ }_{2} \mathrm{I}_{3}$ の $T_{\mathrm{c}}$ が $10.5 \mathrm{~K}$ まで達するこ とを見出した ${ }^{12)}$ 。DODHT 系超伝導体には, 圧力下で様々 な電子相（超伝導相・金属相・絶縁相）を発現するとい う特徴がある。

\section{4. 有機磁性超伝導体}

電荷移動塩を構成する無機アニオンとして, 磁性アニ

オンを用いると, 有機ドナー分子の $\pi$ 電子と磁性アニ オンに由来する $\mathrm{d}$ 電子との協奏効果（ $\pi-\mathrm{d}$ 相互作用）に より, 単独の電子系では発現できない複合物性を示す物 質の構築が可能となる13，14)。たとえば， $\mathrm{Fe}^{3+}$ イオンを 含む BETS 系超伝導体 ${ }^{15)}$ では, 常識とは相反して, 高磁 場をかけると磁気抵抗が急激に減少し, 再び超伝導状態 に戻る現象（磁場誘起超伝導）が報告されている16)。こ のような磁場の増加に伴った磁気抵抗の急激な減少は, (BDA-TTP) ${ }_{2} \mathrm{FeCl}_{4}$ においても観測されている ${ }^{17)}$ 。さら に, BETS 系超伝導体 (BETS) ${ }_{2} \mathrm{Fe}_{\mathrm{x}} \mathrm{Ga}_{1-\mathrm{x}} \mathrm{Cl}_{4}$ では, 温度 を下げると超伝導状態から絶縁状態に転移する現象が見 つかっている。

\section{5. おわりに}

有機分子性導体の研究は, 化学と物理の境界領域とし て大きく発展し，1 つの学問分野を築き上げるまでに至 っている。また, 有機分子性導体は, 将来の電子材料・ 電子素材として注目されている18, 19)。一方，有機超伝 導体の最高 $T_{\mathrm{c}}$ は, 超高圧下 $(8.2 \mathrm{GPa})$ で記録された (BEDT-TTF ${ }_{2} \mathrm{ICl}_{2}$ の $14.2 \mathrm{~K}$ であり ${ }^{20)}$, さらなる $T_{\mathrm{c}}$ の向 上が熱望されている。有機超伝導機構について統一的な 解釈ができていない現段階では，この問題の解決は容易 ではない。しかし, 様々な $\pi$ 電子系から成る有機分子 から超伝導体を開発し, 有機超伝導特性を多角的に明ら かにすれば，この問題を解決する鍵を探し出せるであろ う。

\section{謝辞}

本稿で紹介したビーカー型セルの考案および制御電流 法の開発は, 安西弘行姫路工業大学名誉教授の御功績で あり, また, 安西先生から結晶育成研究に関して多大な る御指導・御助言を賜りました。ここに深く感謝申し上 げます。

\section{文献}

1) J. Ferraris, D.O. Cowan, V. Walatka, Jr. and J.H. Perlstein: J. Am. Chem. Soc. 95, 948 (1973).

2) "TTF Chemistry - Fundamentals and Applications of Tetrathiafulvalene", ed. by J. Yamada and T. Sugimoto (Kodansha \& Springer, Tokyo, 2004).

3) Thematic issue on Molecular Conductors: Chem. Rev. 104, No. 11 (2004).

4) Special topics on Organic Conductors: J. Phys. Soc. Jpn. 75, No. 5 (2006)

5) D. Jérome, A. Mazaud, M. Ribault and K. Bechgaard: J. Phys. Lett. 41, L-95 (1980).

6) H. Mori: J. Phys. Soc. Jpn. 75, 051003 (2006).

7) H. Anzai, J.M. Delrieu, S. Takasaki, S. Nakatsuji and J. 
Yamada: J. Cryst. Growth 154, 145 (1995).

8) H. Anzai, S. Maki, S. Takasaki, S. Tanaka, S. Nakatsuji, J. Yamada and K. Nozaki: J. Cryst. Growth 191, 148 (1998).

9) H. Nishikawa, T. Sato, T. Kodama, I. Ikemoto, K. Kikuchi, H. Anzai and J. Yamada: J. Mater. Chem. 9, 693 (1999).

10) J. Yamada, H. Akutsu, H. Nishikawa and K. Kikuchi: Chem. Rev. 104, 5057 (2004).

11) E.S. Choi, E. Jobilong, A. Wade, E. Goetz, J.S. Brooks, J. Yamada, T. Mizutani, T. Kinoshita and M. Tokumoto: Phys. Rev. B 67, 174511 (2003).

12) J. Yamada, K. Fujimoto, H. Akutsu, S. Nakatsuji, A. Miyazaki, M. Aimatsu, S. Kudo, T. Enoki and K. Kikuchi: Chem. Commun. 1331 (2006).

13) E. Coronado and P. Day: Chem. Rev. 104, 5419 (2004).

14) T. Enoki and A. Miyazaki: Chem. Rev. 104, 5449 (2004).

15) H. Kobayashi, H.-B. Cui and A. Kobayashi: Chem. Rev.
104, 5265 (2004).

16) S. Uji, H. Shinagawa, T. Terashima, T. Yakabe, Y. Terai, M. Tokumoto, A. Kobayashi, H. Tanaka and H. Kobayashi: Nature 410, 908 (2001).

17) E.S. Choi, D. Graf, J.S. Brooks, J. Yamada, H. Akutsu, K. Kikuchi and M. Tokumoto: Phys. Rev. B 70, 024517 (2004).

18) M. Chollet, L. Guerin, N. Uchida, S. Fukaya, H. Shimoda, T. Ishikawa, K. Matsuda, T. Hasegawa, A. Ota, H. Yamochi, G. Saito, R. Tazaki, S. Adachi and S. Koshihara: Science 307, 86 (2005).

19) F. Sawano, I. Terasaki, H. Mori, T. Mori, M. Watanabe, N. Ikeda, Y. Nogami and Y. Noda: Nature 437, 522 (2005).

20) H. Taniguchi, M. Miyashita, K. Uchiyama, K. Satoh, N. Môri, H. Okamoto, K. Miyagawa, K. Kanoda, M. Hedo and Y. Uwatoko: J. Phys. Soc. Jpn. 72, 468 (2003). 